DOI: http://dx.doi.org/10.33846/hn50505

http://heanoti.com/index.php/hn

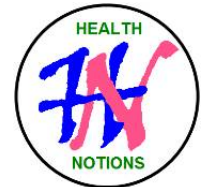

RESEARCH ARTICLE

URL of this article: http://heanoti.com/index.php/hn/article/view/hn50505

\title{
Influences of Contingency Planning in Improving Preparedness of Tough Disaster Village Cadres in Facing Volcano Eruption Disaster in Blitar, East Java, Indonesia
}

\author{
Agus Khoirul Anam ${ }^{(\mathrm{CA})}$, Sri Winarni², Andi Hayyun Abiddin ${ }^{3}$ \\ ${ }^{1(\mathrm{CA})}$ Diploma 3 Nursing Department, Poltekkes Kemenkes Malang, Indonesia; aguskhoirulanam@gmail.com \\ (Corresponding Author) \\ 2Diploma 3 Nursing Department, Poltekkes Kemenkes Malang, Indonesia; swinkhamaisya@gail.com \\ ${ }^{3}$ Diploma 3 Nursing Department, Poltekkes Kemenkes Malang, Indonesia; andiabiddin@ gmail.com
}

\begin{abstract}
The Village cadres' respite of death or of a calamity is the community as leading perpetrator of in the process of bringing into reality the spiritual or postponed for a while as well as technical and village. The purpose of this research to identify the influence of contingency planning in improving disaster preparedness or postponed for a while of having young village people in charge of disaster management deal with disaster of volcanic eruption. The quasi-experimental design was used. We recruited 25 the tough disaster village cadres with a total population sampling method. The analysis of the t-test showed the t-value of -5.269 and p-value of 0.001 , it means that there was significant difference of the preparedness of tough disaster village cadres in facing volcanic eruptions disaster between before and after being given contingency planning.
\end{abstract}

Keywords: contingency planning; preparedness; village; caders; volcano; disaster

\section{INTRODUCTION}

Indonesia is a disaster-prone country from its geographical, climatological and demographic aspects. Indonesia's geographic location between two continents and two oceans means that Indonesia has good potential in the economy and is prone to disasters ${ }^{(1)}$. Moreover, Indonesia is a country that has the most volcanoes in the world, namely 500 volcanoes spread across Indonesia and 129 of them are active volcanoes, about 70 of these active volcanoes often erupt ${ }^{(2)}$. Based on the distribution of high risk zones specified in the ratio index of volcanic eruption disasters in Indonesia, the National Disaster Management Agency has stated that volcanic eruption disaster management within 5 years since 2011 is directed at areas prone to volcanic disasters including Mount Kelud in the Blitar area of East Java ${ }^{(3)}$.

Disaster risk reduction is an effort to mobilize all assets, both material and social capital, including local wisdom as the main capital. The ability to mobilize resources is one measure to measure the resilience of villages. Resource mobilization contains the principle of managing resources in a sustainable manner while at the same time increasing the carrying capacity of the environment against various disaster risks by referring to community needs and rights. The community can build mutually beneficial cooperation with non-governmental organizations, business organizations, and other institutions from outside the community to jointly reduce disaster risk.

According to Law No. 24 of 2007, Disaster Resilient Villages are villages that have an ability to independently adapt to the threat of a disaster and recover quickly from the adverse effects of disasters, meaning that villages in disaster-prone areas should have the ability to recognize threats in their areas and able to organize community resources to reduce vulnerability and increase capacity to reduce disaster risk ${ }^{(4)}$. This capability is manifested in village development planning which includes all forms of efforts to reduce disaster threats and community vulnerabilities, as well as increase preparedness capacity, which is planned and implemented by the community as the main actor. In this case the community is actively involved in assessing, analyzing, managing, monitoring and reducing disaster risks in their area, especially by utilizing local resources to ensure sustainability.

Disaster Resilient Village Cadres are the community as the main actors in the process of realizing a Disaster Resilient Village. Technical support from outside is also very much needed. The success of the outsiders in 
facilitating the community to realize Disaster Resilient Village is the success of the community as well and it is hoped that the community will have the entire process of developing this program itself.

Contingency planning is a process of identifying and compiling contingency planning based on such contingency or uncertain conditions ${ }^{(5)}$. This contingency planning identifies the actions that must be taken by each party involved in disaster management and the resources to be used. Contingency planning for village disaster contingency is only used for one type of disaster, and is legalized by a Village Head Regulation which is based on the legalization system applicable in the local village government. Renkon is carried out as soon as there is an initial sign (of possibility) that a disaster will occur.

To support disaster risk reduction efforts, villages need to establish Disaster Risk Reduction Forums. This forum can be formed specifically or develop groups that already exist in the village. This forum is not part of the official village government structure, but the government can be involved in it together with other components of civil society. Based on the description above, the researcher will conduct research on the effect of contingency planning in increasing the preparedness of disaster resilient village cadres to face the threat of volcanic eruptions.

\section{METHODS}

This study used quasy experimental design. The total of 25 cadres of tough disaster village were recruited with total population sampling technique in Tanggung Village, Blitar City, East Java, Indonesia. After this study had obtained ethical clearance with number Reg. : 491 / KEPK - POLKESMA / 2020. There were three steps the data collection technique; the first step, researcher identified the preparedness of tough disaster village cadres in facing the volcanic eruptions disaster. The second step, researcher carried out the preparation of a contingency plan with involve the cadres of tough disaster village. Finally, researcher measured the preparedness of tough disaster village cadres after the contingency plan is socialized. Moreover, all participants signed an informed consent after obtained written and verbal details on research purposes and procedure documents to participate in this study.

In the descriptive analysis stage, categorical data are presented in the form of frequencies and percentages ${ }^{(6)}$, while numerical data are presented in the form of standard deviation ${ }^{(7)}$. This research used SPSS 17 version to identify the significant differences between the preparedness of tough disaster village cadres in facing volcanic eruptions disaster before and after being given contingency planning were calculated using Paired-Samples TTest.

\section{RESULTS}

Based on Table 1, the majority of the participants were 25 to 30 years old of age (60\%). Most of them were male $(76 \%)$ and more than three years most of the participants became cadre $(60 \%)$.

Tablel 1. Demographics characteristics of participants $(\mathrm{N}=25)$

\begin{tabular}{lcc}
\hline \multicolumn{1}{c}{ Variable } & Frequency & Percentage \\
\hline Age (years) & & \\
$25-30$ & 15 & 60 \\
$30-40$ & 5 & 20 \\
$>40$ & 5 & 20 \\
Gender & & \\
Male & 19 & 76 \\
Female & 6 & 24 \\
Duration become cadres & & \\
(years) & & \\
1 & 5 & 20 \\
$2-3$ & 5 & 20 \\
$>3$ & 15 & 60 \\
\hline
\end{tabular}

Table 2 shows that the preparedness of tough disaster village cadres after the contingency plan had given in facing volcanic eruptions disaster, tends to be higher with mean score was 77.00 than before being given a contingency plan. Moreover, t-value $=-5.27$ and $\mathrm{p}$-value $=0.001$ based on paired samples t-test analysis. It means that there was significant difference of the preparedness of tough disaster village cadres in facing volcanic eruptions disaster between before and after being given contingency planning. These indicated that a contingency 
plan have a positive effect in increasing the preparedness of tough disaster village cadres in facing volcanic eruptions disaster.

Table 2. The differences of the preparedness of the village Cadres in facing volcanic eruptions disaster between before and after being given a contingency plan $(\mathrm{N}=25)$

\begin{tabular}{|c|c|c|c|c|}
\hline \multirow{2}{*}{ Variable } & Pre-treatment & Post-treatment & \multirow{2}{*}{$\mathrm{t}$} & \multirow{2}{*}{ p-value } \\
\hline & Mean \pm SD & Mean \pm SD & & \\
\hline Contingency plan of village cadres & $56.08 \pm 35.46$ & $77.00 \pm 21.88$ & -5.27 & 0.001 \\
\hline
\end{tabular}

\section{DISCUSSION}

This study found that the preparedness of tough disaster village cadres after the contingency plan have given was higher than before in facing volcanic eruptions. In line with previous study that the preparedness of tough disaster village cadres is influenced by contingency planning as a medium that can be used as initial information for the tough disaster village cadres about the efforts that will be carried out when a disaster occur ${ }^{(8)}$. Moreover, the preparedness was carried out to ensure fast and appropriate efforts in dealing with disaster event (5). Preparedness refer to the preparation and trial of a contingency planning for disaster emergency management, such as: organization, installation and testing of early warning systems; provision and preparation of supplies for meeting basic needs; organizing, outreach, training and rehearsals on emergency response mechanisms; site preparation evacuation; preparation of accurate data, information, and updating of disaster emergency response routines; and provision and preparation of materials, goods, and equipment to fulfill the recovery of infrastructure and facilities ${ }^{(1)}$.

The preparedness is a series of activities undertaken to anticipate disasters through appropriate and effective measures to ensure a fast and effective response in the event of a disaster ${ }^{(9)}$. In line with this study that the preparedness of the tough disaster village cadres tends to be less before being given a contingency planning, because the contingency planning is prepared to deal with a crisis situation that is expected to occur soon ${ }^{(5)}$. The contingency planning is a process of identifying and compiling a planning based on these uncertain circumstances (10). The contingency planning is immediate action in the event of a disaster that is expected to occur. The contingency planning seeks to identify possible disasters and their impact on the community and build a collective agreement to share responsibilities in dealing with them, as well as decisions about the mobilization of resources to be carried out ${ }^{(5)}$. This contingency planning identifies the actions that must be taken by each party involved in disaster management and the resources to be used ${ }^{(10)}$. There was a lack of preparedness before being exposed to disaster contingencies because the tough disaster village cadres had not yet understood the identification of disaster events and disaster impacts.

According to the cycle of planning and disaster management, contingency planning is included in the phase of preparedness to face the arrival of a disaster ${ }^{(1)}$. The contingency planning is prepared before an emergency / disaster event, with the nature of measurable. The scope of activities in the contingency planning document is specific which focuses on activities to deal with emergencies. The contingency planning document contains only one type of disaster threat (single hazard) with the actors involved only in that threat ${ }^{(11)}$. So that as a disaster risk reduction actor, after being exposed to contingency planning, the tough disaster village cadres are able to understand and implement the contingency planning.

For contingency in the health sector, namely the implementation of health services for refugees, the implementation of medical treatment for injured victims, the implementation of optimal health referrals, and reducing the risk of disease transmission, especially in the evacuation sites. In this research, apart from being introduced to contingency planning, it is also prepared as a keltana cadre who is capable of carrying out disaster relief in the health sector. Further efforts include establishing a disaster post which is equipped with medical equipment and medicines. Increased preparedness of tough disaster village cadres influenced by contingency planning as a medium that can be used as initial information for the tough disaster village cadres and generally affected communities about the efforts that will be made when a disaster actually occurs ${ }^{(8)}$. Informative and interesting media will be effectively used in increasing one's understanding of an activity. According to ${ }^{(5)}$ the media has benefits in the process of distributing information. Hence, contingency planning is expected to be able to provide accurate information in disaster risk reduction during the pre-disaster phase to serve as a guide for handling disasters during and after a disaster.

\section{CONCLUSION}

This study showed that there was significant difference between the preparedness of tough disaster village cadres in facing volcanic eruptions disaster before and after being given contingency planning. The Contingency 
Planning seeks to identify possible disasters and their impact on the community and build a collective agreement to share responsibilities in dealing with them, as well as decisions about the mobilization of resources to be carried out.

The suggestions were:

1. For PBD Kesbangpolinmas Blitar City

PBD Kesbangpolinmas as the Regional Disaster Management Command and Coordinator to improve all urban villages in Blitar City to make Contingency Planning in order to improve the preparedness of tough disaster village cadres.

2. For the disaster village cadres

All cadres must improve their understanding of Contingency Planning so that they are always ready when a disaster occurs. The data contained on the map must always be updated according to the real conditions in the community.

3. For Tanggung village

The results of media contingency planning can be used by urban villages as a guide in disaster management. Hence, this media must put in the village disaster post which provide information for the entire community.

\section{REFERENCES}

1. BNPB. Decree of the Head of BNPB No. 10, 2012, concerning Management of Logistics Assistance in Disaster Emergency Status. Jakarta: BNPB; 2012.

2. BNPB. Decree of the Head of BNPB No. 251 of 2014, concerning the Appointment of the 2014 Disaster Management Logistics Forum. Jakarta: BNPB; 2014.

3. BNPB. Decree of the Head of BNPB No. 3, 2016, concerning Command Systems for Disaster Emergency Management. Jakarta: BNPB; 2016.

4. Pemerintah RI. UU No. 24 of 2007 concerning Disaster Management. Jakarta: Pemerintah RI; 2007.

5. Lestari P, Paripurno ET, Rianto A, Nugroho B. Disaster Risk Reduction Based on Community through a Contingency Plan for Mount Sinabung. Jurnal Ilmu Sosial dan Ilmu Politik. 2018;21(3):231-45.

6. Suparji, Nugroho HSW, Martiningsih W. Tips for Distinguishing Nominal and Ordinal Scale Data. Aloha International Journal of Multidisciplinary Advancement (AIJMU). 2019;1(6).

7. Nugroho HSW, Badi'ah A. Descriptive Data Analysis for Interval or Ratio Scale Data. Aloha International Journal of Multidisciplinary Advancement (AIJMU). 2019;1(5):121-123.

8. Gupta R, Guptha S. Strategies for initial management of hypertension. Indian J ournal of Medical Research. 2010;132(5):531-42.

9. ADRRN \& UNISDR. Terminology of Reducing the Disaster Risk. Bangkok: ADRRN \& UNISDR; 2010.

10. Alhadi Z, Maani KD, Nurhabibi P, Syarief A. An Analysis of Problem in Contingency Plan in Padang City Composing of Tsunami. 2018.

11. Sikka AK, Rao BB, Rao VUM. Agricultural Disaster Management and Contingency Planning to Meet the Challenges of Extreme Weather Events. 2016;1(January):155-68. 